\title{
Units of Measurement in Social Practices: An Ethnomathematic Study
}

\author{
Marilene Santos \\ Professora Adjunta do Departamento de Educação da \\ Universidade Federal de Sergipe-UFS - Brasil. \\ Campus Prof. Alberto Carvalho. Vice líder do Grupo de Pesquisa Educação e \\ Movimentos Sociais - GPEMS (CNPQ)
}

\begin{abstract}
The present text aims to present results of the research carried out in the rural territories of Sergipe. The mapping of the units of measurement was done as: palm, tarefa, yard, fathom, celamim, present in the social practices of production of the peasant population and its linkage with the school curriculum. The practices were studied, with the support of the ethnomathematical and curriculum theorizing. To understand them, we used the methodological procedures: interview, direct observation and field diary. The research showed: the existence of a set of measurement units different from those used in the standard metric system; that the reference in the definition of units of measurement is the human body; that such knowledge only entered the curriculum indirectly and eventually.
\end{abstract}

Keywords: Agrarian measures - Curriculum - Ethnomathematics - Rural Education

\section{Introduction}

With the accelerated development of technology and sciences in contemporary society, what constitutes knowledge or ways of knowing increasingly requires other ways both in production and in the ways of communicating and disseminating such knowledge. The area of mathematical knowledge, in spite of the notion of inflexibility in a considerable part of its statements and results, accompanies the scientific and technological development, including the recognition of the existence of diverse forms of mathematical knowledge. Velho and De Lara (2011, p.3) in order to explain the coexistence of what they call "formal/academic mathematics and informal mathematics", affirm that "mathematics today can be accepted both as formal and rigorous science, a set of practical skills necessary for survival

The recognition of different forms of production of mathematical knowledge occurs through the term Ethnomathematics created by D'Ambrósio (2009) to argue about the existence of various mathematics. In the same direction Gerdes (1991) in discussing mathematics and school curriculum reaffirms Ethnomathematics as representative of the 'many' mathematics.

Teaching and learning Mathematics today is not only restricted to the memorization and decoding of symbols and forms, but the understanding that the mathematical idea is linked to different processes of comparing, classifying, quantifying, measuring, organizing, inferring and concluding (D'AMBROSIO, 1998).It implies to understand (Wittgenstein, 1987) that "mathematics is an anthropological phenomenon", consequently a human practice (SILVEIRA, 2010), exercised in different contexts, by different groups that use different languages. It is from this notion of mathematical knowledge that this text was constructed.

Its main objective is to present the results of the research carried out in the 2016/17 biennium in five rural territories of the State of Sergipe in the Northeast of Brazil. The aim of this research was to carry out a mapping of units of measurement such as: palm, tarefa, yard, fathom, celamim, present in the social practices of production of the peasant population and their linkage with the school curriculum of the rural schools.It was sought to understand social practices, analyzing a set of relations present in the peasants' daily life.

The field of research was populated and agrarian reform settlements. In order to understand the social practices and the units of measurement involved, we used methodological procedures such as interview, direct observation and field diary. Three people were interviewed in each territory, totaling fifteen people in the five territories mapped out to understand how the land was measured and how to make a cast net, a hammock, a hat, a broom, a rug or a canoe and how measurement units as the fathom, the palm, the inch, the yard. In direct observation, a week was devoted to each territory, totaling five weeks of immersion in the field of research and produced a field diary where it was possible to register feelings, emotions, impressions readings of time and space, in short, the different speeches (SANTOS, 1997). 
In order to reach the objectives of the research and to contribute to the reflection and debate about rural education and school curriculum, the practices were problematized and studied, with the support of the ethnomathematical and curriculum theorizations.

\section{Ethnomathematics and curriculum}

Ethnomathematics is an area of Mathematics Education whose central axis is culture.Ethnomathematical researches seek to understand the social practices of different cultural groups and the mathematical knowledge involved in them, analyzing their linkages with the curriculum. As Knijnik (2004b) states, "Ethnomathematics examines the relationship between curriculum and culture in Mathematics Education". And the author continues: "I consider Ethnomathematics as a toolbox that makes it possible to: analyze the mathematical language games of different life forms... and examine the discourses of academic mathematics and school mathematics and their effects of power" (KNIJNIK, 2015, p. 4) Still in relation to the centrality of culture for ethnomathematics, D'Ambrósio (2009)mentions daily practices that involve mathematical thinking to show how culture is present in these actions. The author says:

Everyday life is impregnated with the knowledge and practices of culture. At every moment, individuals are buying, classifying, quantifying, measuring,... and somehow evaluating, using the material and intellectual tools that are proper to their culture(p.22).

The readings of Ethnomathematics helped to understand the social practices of the peasants surveyed, examining mathematical knowledge present there, without glorifying or folklorizing such knowledge. The look through the lens of Ethnomathematics made it possible to consider the social practices of peasants in the most diverse aspects, such as history, relationships with nature and with other groups, without looking only at numbers, brands that have been socially identified as marks of Mathematics. For Knijnik (2015):

We can consider the mathematics produced in the different forms of life as language games that are constituted by means of multiple uses. Thus, the academic mathematics, school mathematics, peasant mathematics, indigenous mathematics, in short, the mathematics generated by specific cultural groups can be understood as sets of engineered language games in different forms of life, adding specific criteria of rationality(p. 5)

For Ethnomathematics, it is important to "analyze popular cultures from a (relative) perspective of autonomy, associating them with the social conditions of the groups studied, not forgetting that when compared sociologically with hegemonic cultures, they are unequally different" (KNIJNIK, 2004a, p.23). Hence the need to, in this research, historicize the process of implantation of the standard units of measurement in Brazil. In the nineteenth century, this process triggered attempts of resistance, among them, the Quebra-quilos Revolt(SOUTO MAIOR, 1978,).Knijnik (2004a)highlights the importance of this historicizing when he affirms: "It is in this sense that it is possible to understand the relevance given to ethnomathematical thought in regard to the recovery of the present and past histories of the different cultural groups"(p.22).

Another aspect of Ethnomathematics that is also articulated with this research is the problematization, in mathematical education, of the dichotomy between erudite culture and popular culture. This type of problematization has been made by postmodern thinking, which "rejects categorical and absolute distinctions such as that which modernism makes between 'high' and 'low' cultures". (SILVA, 2002, p. 114)

For Ethnomathematics, Academic Mathematics is not only considered as mathematical knowledge. This mathematics produced in the academy is one among many ethnomathematics, because it is produced by a specific social group, "the mathematicians." But for the field of ethnomathematics, popular knowledge, the ways of organizing and producing knowledge of social groups that are not in the academy are also recognized as mathematics, more precisely, they are ethnomathematics. They are a different knowledge, which uses different logics and processes of academic mathematics, but they are also mathematical knowledge. This is one of the aspects that we understand to situate ethnomathematics in a contemporary perspective.

The very conception of culture with which Ethnomathematics works is contemporary, in the sense that it understands it no longer as something fixed, immobile and transferable as a "baggage", but as involving processes in which disputes, struggles "around construction and the imposition of meanings on the social world "(SILVA, 2001, p.14). Knowledge, in turn, will not be considered as something ready to be passed on to future generations. It is also marked by cultural processes, it is resignified, re-created, re-produced permanently through social practices, in all groups, whatever they are. The emphasis on the processes of meaning involved in both the contemporary conception of culture and that of curriculum makes us think of them as social relations. Silva (2001, pp. 21-22) draws attention to this question when he says that if curriculum and culture are practices of signification, then they are necessarily social relations, since practices of signification do not occur in isolation, "free of culture, "but rather in a network of relationships, which are social ones. 
In these relations, disputes are established, negotiations that would be invisible if the culture or the curriculum were seen only as a "product". Even if an attempt was made to see, for example, the curriculum only as a product, always "the features of the disputes over cultural predominance, of the negotiations around the representations of the different groups, of the struggles between, on the one hand, official, on the other, subordinate, relegated, despised knowledge "are inscribed in the curriculum (Silva, 2001, p. 22), always pointing that this is a social relation. The author shows, from these considerations, that "if the social relations within which the practices of signification are realized are not simply social relations, they are more than that: they are social relations of power"(Silva, 2001, p. 23).

In this sense, power can not be considered as alien to the "practices of meaning that constitute the curriculum."On the contrary, it is intrinsically part of these practices. In this game, social identities are built. Moreover, constructed in relation to difference. AsSilva (2001) argues, in producing the difference, we define our identity, which would be as if we said: "I am what the other is not; I am not what the other is ". (p.26).

The curriculum, from this perspective, is directly involved in the process of identity formation. AsSilva (2001) states:

Iracial, sexual identities...From this perspective, the curriculum can not be seensimply as a space for transmitting knowledge. The curriculum is centrally involved in what we are, what we become. The curriculum produces, the curriculum produces us.( p.27).

As the author, in the research in focus, the curriculum is not understood as a mere instrument of transmission of knowledge and culture, but, following Moreira \& Silva (1995), it is understood as "a land of production and of cultural policy, in which existing materials function as raw material for creation, recreation and, above all, contestation and transgression ". (p.28)

These positions lead us to understand that ethnomathematical research is not interested in understanding the practices as frozen, if it can be considered a social practice as such, but in the dynamicity, ambiguity, and hybridity of the cultural processes of the studied groups. It was these ambiguities, these hybrids that sought to be understood in settlements and agrarian reform settlements where the social practices of production were investigated.

Hybridism is understood under two articulated aspects. The first is that mentioned by Hall(2003), who understands it as "the fusion between different cultural traditions - [which] are a powerful creative source, producing new forms of culture". Here hybridity is being used to say of the "blending" of cultures, of "non-purity"(p.91).But there is a second aspect to be considered in the expression hybridism. It is the hybridity of the subjects themselves, which means that, instead of being thought of as havingafixed, stable identity, they are understood as consisting of multiple identities. AsHall (2003) writes: "Within us there are contradictory identities, pushing in different directions, so that our identifications are continually shifting"(p.13).Dussel (2002)when writing about hybridism, relates these two aspects:

One of the basic questions that can be pointed out in the contemporary uses of the term [hybridism] is the rupture with the idea of purity and univocal determinations. Hybridization not only refers to particular combinations of disparate questions, but also reminds us that there are no purely intrinsically coherent forms (identities, materials, technologies of government, etc.), even if this mixture is not intentional(p.65).

Based on the authors of the formal curriculum as (FORQUIN, 1993) (LOPES \& MACEDO, 2011), (SILVA, 2002), (GARCIA E MOREIRA, 2003) and the theorizations briefly presented in this section, social aspects of production that involve the use of units of measure present in the culture of the peasants in the five territories that participated in the research.

\section{Social Practices and Units of Measurement}

This paper describes and analyzes social production practices involving the use of units of measurement present in the culture of peasants and agrarian reform settlements in the five Sergipean territories that were part of the research. The analysis soughttoevidence the knowledge produced there and its effects on the constitution of the subjects, in their identities. Looking at such practices, we have been interested in tensions much more than in consensus, we have been attentive to what escapes the model, the pattern, concentrating on what mixes, what crosses borders, provoking changes and transformations in social practices.

Since the universe of practices with which we are faced in the field work was very extensive, each one involving complex processes and many details, we have chosen to analyze in this text six of these practices: the practice of making cast nets, the practice of producing drag nets, the practice of making straw hats, the practice of making straw brooms, the practice of canoeing, and the practice of measuring land. The choice was made because of the relevance of such practices in the daily lives of the people of the communities. During the field work, we decided to observe the workers for a long period in the practice of these social practices and also interviewed them about the meanings attributed to these practices. 
The social practice of making cast nets was developed by women in the villages and settlements surveyed. The Cast net is a kind of net made with nylon used for individual fishing. Its shape resembles a Christmas tree, it is narrow on top and quite round below. In order to make it sink when thrown into the water, fishermen put pieces of lead all over their wheel. When thrown into the water, the net opens like an umbrella, closing as it lands on the riverbed. In the making of the net, the peasants use the palm as unit of measure. One of the peasants who participated in the research stated that she made: "a fifteen-and-twelve-palms cast net. Their sizes depend on where one is going to go fishing... To measure the net, I measure it in the palm and in the scale, if it's necessary, but I already know that a palm is twenty centimeters long."

In this narrative, the dynamic and creative character of the culture is evidenced and the lack of a unique model to be followed in the practice of making Cast nets. By extending the range of possibilities in making cast nets, farmers ensure the coming and going between what is and what is not, pointing out that there is away, $a$ method of exercising the practice of making fishing nets: there are ways, methods and multiple possibilities.

When he says that he makes nets in different ways, using different methodologies, depending on how the situation demands, he reinforces the understanding of culture as a field of meaning in permanent re-creation, not ready and finished. When he says that he makes the cast nets as much to fish in the shallow as in the bottom, he uses both the palm and the meter, in contrast, in this case, to other narratives that we heard on several occasions, in which they affirmed "not being welcome" in the settlements units of measurement of the standard system.

In the perspective of Cultural Studies, "culture is a power game"(SILVA, 2002, page 134).In this game, the subjects are all the timere-meaning their practices. Creating several possibilities for the weaving of the nets shows the transforming, ambiguous and creative character of this social practice. Even though it is a practice that always repeats itself in the sense that it always occurs in that community, this repetition does not take place in a mechanical, fixed way, it is constantly beingre-understood, including and abandoning aspects and relationships, producing other meanings in life of people.

The social practice of making drag nets is similar to the practice described above, but with some fundamental differences. Trawling is developed by two or more people, who stretch the net all the way into the river or pond where they are fishing. People are divided into two canoes, holding the ends of the net thrown into the water, and rowing and dragging the net toward the riverbank. Fish that are in the space in which the net passes are trapped in their meshes. At other times, the net is stretched, remaining on the spot waiting for the fish to be caught in their meshes. Only then will the net be collected. Nets for this type of fishing are also made mainly by peasant women and are made only to the fishermen, who negotiate directly with the net makers in the villages or in the settlements.

The unit of measure used to determine the length of the net is the fathom. In the surveyed areas, the unit fathom is determined by the distance between the middle fingertips of a person with arms wide open. This measurement for the fathom is apparently unrelated to the length measurement used in some Brazilian regions where one fathom is equal to 2.20 meters. According to Knijnik (2000, p. 23), some workers from settlements in Rio Grande do Sul, in order to determine the extent of land to plant rice, use the fathom that corresponds to 2.20 meters. The fathom employed by the peasants in sergipean territories, does not have equivalence with the standard metric system.

The fathom is a cultural artifact that integrates the social practices of the communities that participated in the research. Translating the length of the arm in the standard metric system may not be very important here because there was a variation (even if small) in the size accepted in that peasant culture. In this sense, the non-translation or mere transformation of the fathom in meters and centimeters can be thought of as untranslatable. Burbules (2003) talks about this question: "(...) there are untranslatable differences, or where translation implies not only the inclusion of $\mathrm{X}$ in the language of $Y$, but a fundamental redefinition of both $X$ and $Y^{\prime \prime}(p .180$-181).Following the author, we could infer that it did not make sense for those peasants to accurately translate the fathom into the standard metric system, for such an attempt would be reducing that sensuous activity to the group only to a numerical result.

The practice of weaving and sewing straw hats differs from the previous two because it is an activity developed only at certain times of the year, during the period characterized as having the most sunny days, usually spring and summer. In autumn and winter, when there is more rainfall, this activity is interrupted because moisture damages the straw used in the weaving of these artifacts. The straw hat production process - which is not carried out individually - consists of several stages, starting with the removal of the straw and ending with the sale of the hat.

\footnotetext{
${ }^{1}$ The unit of measure was used by the peasants to measure the size of the net for trawling and for the size of the braid in the making of a straw hat.
} 
In the field research, it was observed that the practice of producing the hats begins with the removal of the green straw from the aricurizeiro ${ }^{2}$.These straw are put to dry in the sun and only after drying the braids are made. When the braids are ready, the hats are assembled and sewn together. According to the report of the peasants, the production of a hat for an adult person requires a braid of four and a half fathoms, and for a child, usually the braid with three fathoms is sufficient. As in the peasant communities, the fathom is not considered in reference to the metric system, since the measures-as mentioned previously, when referring to the fathom used to measure trawling nets -, the span and the inch are also not referenced by the metric system. The peasants regulate the length of the braid by closing the arm or adding an inch or more to have the size of the suitable fathom for each hat.

The social practice of making brooms resembles the former one because it is a process that also consists of several stages. Another similarity between the two practices is related to the raw material. The brooms are made with the same material used in the making of the hats, the aricurizeiro straw. They are the leftovers, the hardest part of the straw that is not used to make the braids for the hats that the peasants use to make the brooms.

The benchmark was the hand. Two units of measure were used, the palm and the inch. The palm, as previously mentioned, is the distance between the tip of the little finger to the tip of the thumb, measured with the open hand. The inch is a measure that is the size determined by the distance between the tip of the thumb to the tip of the index finger, when both are as far apart as possible. This unit of measurement, like the fathom and the palm, as previously mentioned, was also not used having an equivalence in the standard metric system.

The social practice of building canoes was identified in only one agrarian reform settlement. It is a practice restricted to a few people, usually men, and controlled by the community with the support of an internal regulation. In the construction of the canoes, the peasants said to use the palm as unit of measure. According to them, the sizes of the canoes vary according to the amount of people it supports. They build all sizes, from the smallest, to only two, to the largest, in which up to ten people can travel. The most requested by the peasants are the ones that support up to three people, mainly used to fish.

The social practice of measuring land was generally developed in the planting and harvesting periods of agricultural production. Most of those who measured were men, and there was much difficulty between them in performing the measurement calculations. During the research it was possible to verify that the social practice denominated by the peasants as "measuring land" was denominated by some of them of "cubar the land". This expression was also mentioned by Knijnik(1996,p.39 ) when he analyzed the social practice of land use used by farmers linked to the MST.In the two methods analyzed, it was found that "popular methods of land cover were approximations of the areas of the surfaces that had to be measured".

To cubar the land, the peasants used the tarefa as an area unit, one tarefa being equivalent to 25 square yards ${ }^{3}($ often called, in the researched settlements, 100 yards). When asked to explain the process of measuring area on tarefas a peasant gave the following explanation:

The measurement of a tarefa is 25 yards in a frame, there is a tarefa. This is the right tarefa, 25 yards in each firebreak ${ }^{4}$.But not all land is square. Sometimes the land has 20 yards of mouth - width - and 30 yards in each firebreak - length. There you have a tarefa, as long as you have 100 yards in total.

To measure the land, that is, to calculate its area, the instrument used in the communities was the stick. The reference in the definition of the length of the stick was the whole body. The peasants also explained the process of building the stick as an instrument of measurement:

I stand here with my arm raised [pointing to the middle finger] and I still add three fingers, a mark here on the tip of this finger, and I add three more fingers. I make it for anybody who wants to measure it and it is that size that he is saying there( 2 meters and 20 centimeters). Without ameter, with nothing.

In describing the construction of the stick, the peasants could no longer separate the cultural reference from their group from the standardized reference of the official metric system, that is, its equivalence to $2.20 \mathrm{~m}$. Anequivalence that in the settlements of agrarian reform, had to incorporate when of the process of possession of the land.

\footnotetext{
${ }^{2}$ The aricurizeiro is a well-known plant in the region of Sergipe. From the family of palmáceas (Cocos coronata), it produces aricuri, a type of edible coconut. The aricurizeiro is also known as ouricuri, adicuri and dicuri (Source: dictionary Aurelio)

${ }^{3}$ A square yard (an expression which, in the fieldwork, we have not heard) corresponds to the area of a square of side equivalent to a yard: 2,20m.Its equivalence in the metric system is $44.44 \mathrm{~m}^{2}$. Thus, 25 square yards are equivalent to $1,111 \mathrm{~m}^{2}$ ${ }^{4}$ The term aceiro translated as firebreak was used by farmers to name the boundaries (sides) of the land area to be measured. 
In order to measure land, the peasants claimed that the yard (stick) and the tarefa were the only measures they used in the settlements. They also reported that they were forced to standardize the yard to $2.20 \mathrm{~m}$ as the units of the official metric system were imposed on them, especially when they gained possession of the land and had to divide it into equal lots among the families. In order to determine the size of the area to be settled, as well as the size of the lot that would fit each family, the National Institute of Colonization and Agrarian Reform - INCRA uses the hectare - a measure of the official metric system that corresponds to $10,000 \mathrm{~m}^{2}$ or the area of a side square equivalent to $100 \mathrm{~m}$. The peasants, they reported, did not understand this language - that of the official metric system-and thus created a great problem for them, because they had the land but did not know how much it would fit for each family. This situation forced both INCRA, through its technicians, and the peasants themselves to promote a "translation" of the hectare into tarefas, so that people understood how the settled area had been distributed.

Nowadays, talking about the construction of the measuring instrument, the stick, for the peasants/settlers implies, therefore, to make use of two references: the human body and the meter. Peasant reports have shown that this issue is not quiet, they constantly question their measures, because they are not isolated from the world, they coexist with situations where only standardized measures are accepted, and maintaining a different way of measuring can often be in trouble. At the same time, these are the measures that the vast majority knows, they way they handle and trust in them. Fixing the stick at $2.20 \mathrm{~m}$ was necessary to standardize the measurement size. This standardization ensured, to a certain extent, that the equivalence of the lot area measured by INCRA in hectares with the area expressed by the tarefa unit.

\section{Learn, Teach, Silence}

During the research, when accompanying communities in their production practices, it was possible to observe how children were introduced and taught about them. They would learn it by observing their parents and other people in the community when they exercised a certain activity.The "methods" of teaching included, in addition to observation, attempts by the children themselves to carry out the practices, that is, instead of just observing adults making a cast net, for example, they actually tried to make it themselves as well.

On several occasions, one can observe children trying to make some of the handicraft products that are produced in the communities using the units of measurement of the local culture. In one of the villages, when we arrived to interview a peasant, we found three children "playing" of making a net. One of them had a toy basket on the lap with nylon and weaving needle. While one of them would "weave", the other two children watched, waiting their turn to weave as well, since there was only one needle and they would take turns. We see an active learning process in action.

A similar learning process was analyzed by Duarte (2003) when conducting her research with construction workers in Rio Grande do Sul. According to the author, "most of them joined this profession very early... They were joined by their fathers or some close relative" (p.42). The author affirms that it was common the presence of children of the workers in the construction sites, accompanying and sometimes helping their parents. On one of the moments of children learning in the construction sites witnessed by the author, she reports the following:

(...) on the sites, I observed the presence of the children of Mr. Aristides, Mr. Pedro, Mr. Luis and Mr. Valmir already learning the mason profession. The youngest (...) Idnei and Ivonei, aged eight and thirteen (...)On many occasions, Ivoneitried to take on the task of "mixing the mass" by himself, but he was prevented by the servant, who allowed him to only fill the buckets with water.But when the servant was not around, he filled the shovel and threw it into the concrete mixer, participating in the process of preparing the mass that would be used for the concrete of a slab(p.42).

The author goes on to relate the attempts of the child to make the concrete mixer work until successful, when it comes to occupy another statusin the group of masons, that of who has surpassed an important barrier and has gained another place in the adult world. In this research, we also sought the school of the peasant communities to know how the knowledge produced in the daily lives of the people constituted the school curriculum. We interviewed teachers and students.

The study showed us that the units of measure that integrate peasant culture, such as fathom, span, palm, inch, tarefa and yard (stick), only "entered" the school very indirectly and eventually. Only in art classes, students were invited to present the crafts of their community. From the narratives we listen to and from what we observe, this has been the only space in which the school in these communities has allowed the knowledge of the social practices of peasant families to become present. As one student explained:"The school only works with this type of subject in the Arts course, because there each one takes his/her art to show.An example, if, in art class, I take the cast net to show, is not only to show, I have to take it, weave it and explainto everyone how to make it."

Thus, the school that we observed was a school that does not articulate itself to the peasant life, it is a school that is in a rural area, but with the strong marks of the urban one. There was, at least apparently, nothing that could be identified as marks of an education planned and organized for the specificities of that rural environment. 
Knijnik (2001) has problematized this question, saying that "rural school, thus, is a school that, being there, is out of there."And continues the author: "There are millions of children who, in school, see their world always hidden, either through what appears in textbooks, or through the contents that are worked in the classroom, contents of the city"(p.142).

This idea presented by Knijnik is also present in the narrative of one of the teachers that we interviewed during the research, she affirms that the workers there always "measured the cast nets by palms, fishing net and braid of hat for fathoms and land by yards (stick), but the measures which were taught at school were the measurements of the standard system, the meter, the centimeter, the hectare. "These findings are corroborated by another teacher when she states that:"I only work with the standard system measurements. Tarefas measures do not come into my work." According to Knijnik (2001):

When we treat this particular [academic] Mathematics as the only possible one to exist, the only legitimate one to be present at school, we are silencing voices that, throughout history, have been systematically silenced. Such silences produce very particular people, contribute to building successes or school failures as well as failures and successes of life(p.143).

We can see from the field research that in these communities (settlements) there was a very great mismatch between the school life of the children and young people and the peasant life "outside" the school. The knowledge present in the social practices that were created and recreated by the people of the community seemed not to be known to those in charge of the school. Factor that leads us to reflect on the place that the school has occupied in the rural environment and on how much the peasant culture, in the scope of mathematical education, is absent there.

Some teachers, in their narratives, said they did not know how to organize a school that, as Caldart and Schwaab (1991) affirm, "engaged in the organization of a specific social group... [could] assume singular characteristics and answer questions of this group "(p.102). We understand that, in the teachers' narratives, there was a request for help in order to create conditions that would make it possible to think of a school in the parameters of the Rural School proposed by Caldart (2000).According to the author:

A rural school is not, after all, a different type of school, but rather it is the school recognizing and helping to strengthen the rural people as social subjects, which can also help in the process of humanizing the whole of society with its struggles, its history, its work, its knowledge, its culture, its way(p.66).

The realization of this research showed that the social practices of production and the units of measurement involved are part of the "history, work, culture" of the peasants in the five Sergipean territories. Possibly, having such practices and units of measure represented in the school curriculum as contemporary curriculum theorizations and ethno mathematics have shown can contribute to improving the quality of education and strengthening the peoples of the countryside as social subjects of rights.

\section{References}

BURBULES, Nicholas C. (2003). Tradução de Dinah de Abreu Azevedo. Uma Gramática da Diferença: algumas formas de repensar a diferença e a diversidade como tópicos educacionais. IN: GARCIA, Regina Leite e MOREIRA, Antonio Flávio Barbosa (orgs). Currículo na Contemporaneidade: incertezas e desafios. Cortez, São Paulo. $159-188$.

CALDART, Roseli Salete (2000). A Escola do Campo em Movimento. IN: BENJAMIM, César e CALDART, Roseli Salete. Projeto Popular e escolas do Campo: por uma escola básica do campo. Brasília, DF, p. $41-87$. Coleção Por uma Educação Básica do campo, n. 3).

CALDART, Roseli Salete \& SCHWAAB, Bernadete (1991). A Educação das Crianças nos Acampamentos e Assentamentos.In GORGEN, Frei Sérgio Antônio e STÉDILE, João Pedro. Assentamentos: A Resposta Econômica da Reforma Agrária. Vozes, Petrópolis - RJ. p. 85 - 114.

D’AMBROSIO, Ubiratam ( 2009). Etnomatemática:elo entre as tradições e a modernidade. 2. ed. Belo Horizonte: Autêntica.

D’AMBROSIO, Ubiratam (1998). Etnomatemática: arte ou técnica de explicar e conhecer. 5. ed. São Paulo: Ática.

DUARTE, Claudia Galvam (2003). Etnomatemática, Currículo e Práticas Sociais do "Mundo da Construção Civill". São Leopoldo, RS. 126 f. Dissertação (Mestrado em Educação) - Centro de Ciências Humanas, Universidade do Vale do Rio dos Sinos.

DUSSEL, Inês (2002). O currículo híbrido: domesticação ou pluralização das diferenças? IN: LOPES, Alice Casimiro, MACEDO, Elizabeth (org.) Currículo: debates contemporâneos. São Paulo. Cortez. 
FORQUIN, Jean-Claude ( 1993). Escola e Cultura: as bases sociais e epistemológicas do conhecimento escolar. Trad. Guacira Lopes Louro. Porto Alegre. Artes Médicas.

GARCIA, R. L \& MOREIRA, A. F. B. (orgs.) (2003). Currículo na contemporaneidade: incertezas e desafios. São Paulo: Cortez.

GENTILI, Pablo \& ALENCAR, Chico (2002). Educar na Esperança em Tempos de Desencanto. 2 ed. Petrópolis/RJ: Vozes.

GENTILI, Pablo ( 2003). Reinventar a Escola Pública: política educacional para um novo Brasil. Petropólis. Vozes.

GERDES, Paulus (1991). Etnomatemática: cultura, matemática, educação. Maputo: Instituto Superior Pedagógico.

HALL, Stuart (2003). Tradução Tomaz Tadeu da Silva e Guacira Lopes Louro. A Identidade Cultural na PósModernidade.DP\&A, Rio de Janeiro, RJ.

IBGE (2017). Pesquisa Nacional por Amostra de Domicílios/PNAD Contínua - educação. Rio de Janeiro.

KNIJNIK, Gelsa (2015).Fazer perguntas... ter a cabeça cheia de pontos de interrogação: uma discussão sobre etnomatemática e modelagem matemática escolar.IN:UNIÓN Revista Iberoamericana de Educação Matemática, n. 44, p. $10-23$, diciembre.

KNIJNIK, Gelsa, WANDERER, Fernanda, OLIVEIRA, Cláudio José de. (orgs.) (2004ª). Etnomatemática: Currículo e formação de professores. Santa Cruz do Sul, Edunisc.

KNIJNIK, Gelsa ( 2004b). Etnomatemática: aportes Teóricos e Metodológicos. Belo Horizonte, MG. Palestra proferida na UFMG em dezembro de 2004.

KNIJNIK, Gelsa( 2001). Educação rural: nos silêncios do currículo. IN: SCHMIDT, arai(org) A Educação em Tempos de Globalização. DP\&A, Rio de Janeiro.

KNIJNIK, Gelsa (2000). Etnomatemática na luta pela terra: "uma educação que mexe com as tripas das pessoas”. In: FOSSA, A. (Org.). Facetas do diamante: ensaios sobre educação matemática e historia da matemática. Rio Claro: Sociedade Brasileira de Historia da Matemática. p.11-29.

KNIJNIK, Gelsa (1996). Exclusão e resistência: educação matemática e legitimidade cultural. Porto Alegre: Artes Médicas.

LOPES, Alice C. \&MACEDO, Elizabeth ( 2011). Teorias de currículo. São Paulo: Cortez.

MOREIRA, Antonio Flávio Barbosa \& SILVA, Tomaz Tadeu da ( 2013). Currículo, cultura e sociedade. 12. ed. São Paulo: Cortez.

RAMOS. Marise Nogueira (2006). A Pedagogia por Competências. 3ed. São Paulo: Cortez.

SANTOS, Luís Henrique Sacchi dos (1997). "Um preto mais clarinho..." ou dos discursos que se dobram nos corpos produzindo o que somos. In: Educação \& Realidade, n.22, jul/dez. p. 81-115.

SILVA, Tomaz Tadeu da (2002). Documentos de identidade: uma introdução às teorias do currículo. 2.ed. Belo Horizonte: Autêntica.

SILVA, Tomaz Tadeu da (2002).O currículo como fetiche. Belo Horizonte: Autêntica.

SILVEIRA,Marisa Rosâni Abreu da 2010).Linguagem Mmatemática e Comunicação: um enfoque interdiciplinar.IN: AMAZÔNIA - Revista de Educação em Ciências e Matemáticas V.6 - n. 11 - jul. 2009/dez. 2009, V. 6 - n. 12 jan 2010/jun. 2010

SOUTO MAIOR, Armando (1978). Quebra-quilos: lutas sociais no outono do império. São Paulo: Companhia Editora Nacional.

VELHO, Eliane Maria Hoffmann e DE LARA, Isabel Cristina Machado (2011) O Saber Matemático na Vida Cotidiana: um enfoqueEtnomatemático.ALEXANDRIA Revista de Educação em Ciência e Tecnologia, v.4, n.2, p.3-30, novembro.

WITTGENSTEIN, Ludwig (1987). Observaciones sobre los Fundamentos de la Matemática. Madrid: Alianza Editorial. 